\title{
Local Knowledge: Sex Determination on Vasconcellea Pubescens A.DC in Java, Indonesia
}

\author{
Ainun Nikmati Laily ${ }^{1}$, Purnomo ${ }^{2}$, Budi Setiadi Daryono ${ }^{3}$ and Aziz Purwantoro ${ }^{4}$ \\ \{nunlaily@gmail.com ${ }^{1}$ \} \\ Faculty of Biology, Gadjah Mada University \\ Jl. Teknika Selatan, Senolowo, Sinduadi, Mlati, Sleman, Yogyakarta
}

\begin{abstract}
Vasconcellea pubescens A. DC. is a fruit commodity that has the potential to be researched and developed This plant is the only member of the Family Caricaceae found in Indonesia There are 3 areas in Java that are overgrown with this plant: Dieng Plateau, Bromo, and Cangar-Batu with an altitude of 1500 - 2400 above sea level around the volcano area However, plants are known to have a variety of flower expressions in different trees It is necessary to know the determination of sex as an efficient effort inbreeding This research is a descriptive exploratory study with survey methods, semistructured interviews and strengthened by a questionnaire. Retrieval of data in this study using a simple random technique. Utilization of plants as sweets and as fresh fruit for direct consumption. The utilization of plant organs includes ripe fruit and seeds. The knowledge of the local community regarding the determination of sex in this plant is still limited.
\end{abstract}

Keywords: Local knowledge; Sex determination; Vasconcellea pubescens A.DC., Java, Indonesia

\section{Introduction}

Vasconcellea pubescens A. DC. or "karika" or "mountain papaya" are plants originating from tropical America precisely from the highlands of the Andes, South America. This plant was introduced to Indonesia in the period before World War II by the Dutch East Indies colonial government and was successfully developed in the Dieng Plateau. In other parts of Indonesia, V. pubescens A. DC. can be found in the Bromo and Cangar, East Java. Since 2011, this plant has been widely studied because of its potential as medicinal plant material. Biodiversity studies are now getting a lot of attention both at the national and international levels. Biodiversity studies consist of inter and intra-type diversity as well as inter and intrapopulation diversity. Information on genetic relationships between individuals within and between species has important uses for the improvement of V. pubescens A. DC. So that they can be transplanted in other areas, thereby expanding the distribution area of plants.

The study of V. pubescens A. DC. as a medicinal plant and its potential for health began to be developed, following the studies in question. Characterization based on morphology, antioxidant capacity, and analysis of protein banding patterns for C. pubescens Lenne \& $\mathrm{K}$. Koch [1]. Furthermore, the antibacterial activity of V. pubescens A. DC. leaf extract from the Dieng plateau against diarrheal-causing bacteria studied showed that ethyl acetate and n-hexane fraction of leaf extract significantly had antibacterial activity against Shigella flexneri and Bacillus cereus [2]. Analysis of carbohydrate content resulted in a tendency for more mature V. 
pubescens A. DC. fruit to increase in total carbohydrate content, but the crude fiber content decreased [3]. Plant V. pubescens A. DC. produces vitamin C which is an acidic compound and is useful as a source of antioxidants [4]. V. pubescens A. DC. seed extract also caused death in A. aegypti mosquito larvae at 24 and 48 hours of exposure [5]. The fruit content has also been studied as a source of flavonoids [6].

Study results on the antioxidant activity of leaf ethanol extract using DPPH method showed antioxidant activity with an IC50 value of $30.8 \mathrm{ppm}$ [7]. Fruit of V. pubescens A.DC positively contains flavonoids, polyphenols, tannins, and triterpenoids [6]. It was also explained that the active compound of cysteine protease and papain in the plants of V. pubescens A. DC. had the ability as anti-diabetic compounds [8]. V. pubescens A. DC. in Indonesia is found with a variety of flowers, including male, female and amphisexsual flowers. Local people's knowledge of the variety affects the productivity of the carica plant. This study aims to determine local knowledge about sex determination in V. pubescens A. DC. The results of this study can illustrate the need for us to evaluate the way to determinate sex in V. pubescens A. DC. clearly.

\section{Materials and Methods}

This research was conducted from December 2020 to March 2021 in East Java and Central Java. The method used was a survey by interviewing respondents who were randomly selected (purposive random sampling) and direct observation. The questionnaire method was carried out semi-structured to several respondents with the following respondent criteria are residents whose surrounding area is overgrown with V. pubescens A. DC. in Dieng Plateau, Bromo, and Cangar-Batu. Questionnaires were administered to obtain data regarding knowledge about the sex determination of V. pubescens A. DC. in Java, Indonesia. The research data that has been collected were analyzed descriptively.

\section{Result and Discussion}

The exploration in Dieng Plateau, Central Java, and several places in East Java reported that V. pubescens A. DC. can be found in three places: Dieng Plateau, Central Java; Tahura R. Soeryo People's Forest Park Area, Cangar - Batu, East Java; and Bromo, Pasuruan, East Java. The map of the observation area on the island of Java, Indonesia is shown in Figure 1.

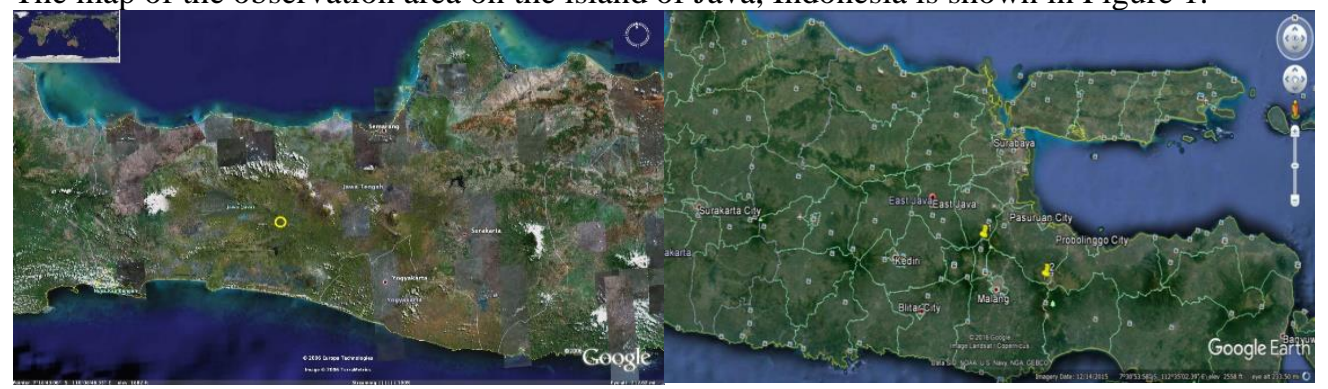

(a)

(b)

Fig 1. (a) Map of Central Java; (b) Map of East Java (The image marked in yellow shows the location where it was found V. pubescens A.DC., in Batu and Pasuruan). 
In Dieng Plateau, several points where V. pubescens A. DC. grew to be close together. In this location, V. pubescens A. DC. grows both cultivated and growing wild. Likewise, several growing points in Cangar and Bromo. From the exploration activities, it is seen that the distribution of V. pubescens A. DC. in the three areas is irregular. V. pubescens A. DC. grows between agricultural land and people's homes. These plants also grow on roadsides to recreation areas and in places that are not easy to reach. In some of these areas, V. pubescens A. DC. can be found clustered or solitary.

There are several indicators in the investigation of local knowledge on sex determination of V. pubescens A.DC., including knowledge of the existence of plant growth, ownership of plants, utilization of plants for daily needs, the parts of plants used, obtaining seeds or plant seeds, how to plant, the origin of plants growing in that place, the types of plant sex, and how to differentiate between plants of different sex.

In the three exploration areas in Dieng Plateau, Bromo, and Cangar-Batu, local people within a radius of no more than 300 meters are sufficient to know the existence of $\mathrm{V}$. pubescens A. DC. Local people can explain well the points of growth of the plants and explain other possible places where the plants grow. In the Dieng Plateau, many V. pubescens A. DC. are found at an altitude of 1900 - 2400 meters above sea level, most of them are plants that are deliberately cultivated on agricultural land even though wild plants are also found. In Bromo, at an altitude of 1897 meters above sea level, V. pubescens A. DC. found growing wild in between people's homes and agricultural land and there is one cultivated agricultural land. In CangarBatu, this plant grows wild at an altitude of 1671 meters above sea level at several points around hot springs, around residential areas, and in the agricultural land of Brawijaya University.

Not all local people have V. pubescens A. DC. plants, some people cultivate it in several more than 10 trees and some others do not. On the Dieng Plateau, V. pubescens A. DC. in large quantities and almost uniformly in an agricultural land belonging to the farmer who is the supplier for the confectionery entrepreneur. In Bromo, it is known that one part of agricultural land belongs to farmers which are land for cultivation, the rest grows wild. In Cangar-Batu, it is known that one part of agricultural land belonging to Brawijaya University is used for the cultivation of V. pubescens A. DC.

Not all local people take advantage of these plants, either their plants or obtain them from other people for their daily needs. In the Dieng Plateau, this plant has been widely used, including seeds for nurseries and ripe fruit for sweets as a typical product of the Dieng Plateau which has long been known in Java, Indonesia, and managed by several business entities. According to the narrative of one of the confectionery producers V. pubescens A.DC., the plants on their land have not yet produced fruit, so the producer body relies on 5 suppliers who are supply the fruit in large quantities. Fresh fruit for direct consumption. Meanwhile, in Bromo, the local people are known as "karikaya" and some local people rarely use this plant even though the plant often thrives wildly in dense residential areas. As for its use, it uses ripe fruit. In Cangar-Batu, as in Bromo, this plant is not widely cultivated and is not widely used in everyday life. V. pubescens A. DC. in Cangar-Batu is an area far from densely populated settlements, almost the same as the area overgrown with these plants in the Dieng Plateau.

Generally, local people do not know the exact origin of V. pubescens A. DC. seeds. The local people know that the area where they live have been around for a long time. There are various stories about the origin of these plant seeds. The local people know that the plant was developed from seeds and cuttings. In Dieng Plateau, the origin of this plant cannot yet be explained well, there is information that in the period leading up to World War II the Dutch East Indies colonial government succeeded in introducing and developing these plants in the Dieng Plateau. Cultivators of V. pubescens A.DC in Dieng Plateau are found in large quantities and 
wide cultivated land so that seeds can be obtained easily from farmers. In Bromo, the origin of V. pubescens A. DC. is not yet clearly known by the local community, it is known that there is only one cultivator in the area. In Cangar-Batu as in Bromo, the origin of the plant cannot be explained properly, the seeds are obtained from residents to residents. Cultivation location of V. pubescens A. DC. It is known that only one and is located in separate land by Universitas Brawijaya academics who are obtained from other regions.

Local knowledge is limited on sex determination. The different types of sex are not well explained. In the Dieng Plateau, you can find more trees with bulging and tight fruit. In Bromo, local people tell of the types of trees that are often found with female flowers bearing lots of fruit and meeting. In Cangar-Batu, different types of sex are not yet a concern of the local community. Local people have not differentiated these plants into different sexes. This is different from the use of male Carica papaya L. flowers by local people in Java, in general, to be processed into food and not the case for female flowers. Local people, in general, have not explained well the different types of flowers in V. pubescens A. DC.

Several types of V. pubescens A. DC. based on the morphology of interest found in exploration activities as shown in Figure 2.

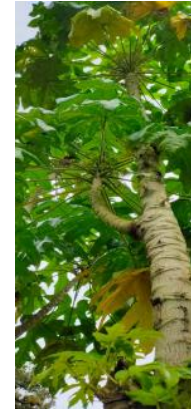

(a)

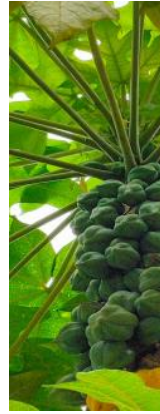

(b)

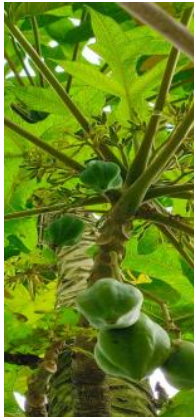

(c)

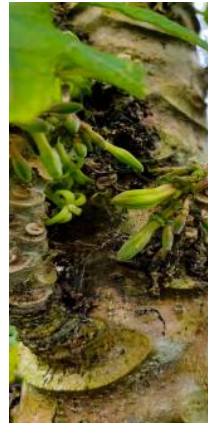

(d)

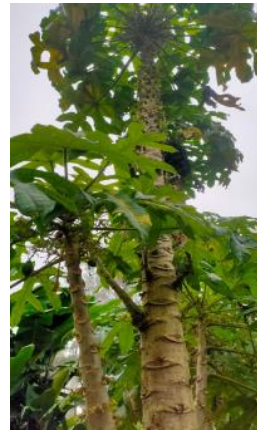

(e)

Fig 2. (a) a tree with male flowers (no fruit at all); (b) a tree with female flowers (the fruit is swollen and short-stemmed) with a large number of fruits (c) a tree with male and female flowers (the fruit tends to be smaller and long-stemmed with a large number of fruits); (d) a tree with male flowers and flowers similar to male flowers that are slightly swollen (no fruit at all); (e) a tree with male flowers (the fruit tends to be smaller and long-stemmed and the number of fruits tends to be very few, around 1-3)

Investigation of local knowledge that can be used to determine the sex of V. pubescens A. DC. in Central Java and East Java showed a significant difference. In Dieng Plateau, their limited knowledge in identifying the sex of the carica plant is since most people know and use the fruit very well but not interest to the flowers. Local knowledge of the Family Caricaceae with its uniqueness in the sex of the flower and the type of plant dioecius is poorly understood. The same thing happened to the local knowledge of the people in Batu and Pasuruan which incidentally V. pubescens A.DC grows only in certain places and is not popular as the plants that grow in Dieng. 


\section{Discussion}

V. pubescens A. DC. which grows in the Dieng Plateau area, apart from being a plant that can grow wild, it is also a cultivated plant in a large and wide area, in contrast to these plants that grow in Bromo and Cangar-Batu whose cultivation is still limited and many are found to be growing wild. There are artificial changes caused by humans, namely there are types of changes made by humans in the form of cultivated plants, including structural changes [9]. Structural changes, although generally heritable, are nevertheless often the result of environmental influences during plant life. Ecological factors or environmental factors are many and varied, often mixed in a complex and dependent manner. Whether isolated or in combination, various ecological factors can contribute to absence or presence, fertility or weakness, and the relative success or failure of various plant communities through their constituent taxons [9].

Morphological characteristics of flowers as organs of generative reproduction of plants did not show any variation in V. pubescens A. DC. which grows in the three observation areas. Flowers at various heights uniformly have male and female flower types with short-stemmed and long-stemmed fruit types. In female flowers, it is known that the base of the flower is round, the shape of the curved edges of the threaded petals, the position of the ovary to the base of the flower sitting right at the base of the flower, stamens, crowns, and ovaries.

In Indonesia, species in the Caricaceae Family other than V. pubescens A. DC. which was found with a greater number and wider distribution was Carica papaya L. Thus, studying the morphology of flowers, sex, and local knowledge of Carica papaya L. was very necessary to clarify knowledge about sex determination in V. pubescens A. DC. It is known that Carica papaya L. is a tropical fruit plant that has health benefits, high commercial value, and is available throughout the year. Production of free-seeded papaya seeds / pure lines must pay attention to the morphology of the flowers and the type of pollination. The type of pollination in papaya is divided into two, namely self-pollinating plants and cross-pollinating plants. Papaya is included in the self-pollinating group, for example, Kapoho, Sun-rise Solo, and Eksotika [10].

Papaya which has a type of hermaphrodite flower that is cleistogamous is included in the self-pollinating papaya group [11]. Papaya varieties that have large fruit sizes are usually included in the cross-pollinate group [12]. Papaya plants have three sexes of flowers, namely male plants, female plants, and perfect plants [13]. Male plants only produce male flowers, female plants only produce female flowers (without any pollen), and perfect plants produce two types of flowers, namely male flowers and perfect flowers. When viewed from the type of flowering, papayas are classified as dioecious (male and female flowers on separate plants) or gynodioecious because they have perfect flowers (multi-sex flowers). The female flowering papaya has a round fruit shape and has few seeds [10].

\section{Conclusion}

The results showed that the local knowledge regarding the determination of sex in $\mathrm{V}$. pubescens A. DC. is still limited.

\section{Acknowledgements}

Throughout the writing of this manuscript, I have received a great deal of support and assistance. I would first like to thank my supervisor, Professor Purnomo, Professor Budi Setiadi 
Daryono, and Mr. Aziz Purwantoro whose expertise was invaluable in formulating the research questions and methodology. Their insightful feedback pushed me to sharpen my thinking and brought my work to a higher level. I would like to acknowledge the local community in Dieng Plateau, Bromo, and Cangar-Batu for their wonderful collaboration.

\section{References}

[1] S. Ainun Nikmati Laily, Suranto, "Characterization of Carica pubescens in Dieng Plateau, Central Java based on morphological characters, antioxidant capacity, and protein banding pattern," Nusant. Biosci., vol. 4, no. 1, pp. 16-21, 1970, doi: 10.13057/nusbiosci/n040104.

[2] D. S. dan A. S. Novalina, "Aktivitas Antibakteri Ekstrak Daun Carica pubescens dari Dataran Tinggi Dieng terhadap Bakteri Penyebab Penyakit Diare," El-Vivo, vol. 1, no. 1, pp. 1-12, 2013.

[3] R. Fitriningrum and A. R. I. Susilowati, "Analisis kandungan karbohidrat pada berbagai tingkat kematangan buah karika (Carica pubescens) di Kejajar dan Sembungan, Dataran Tinggi Dieng, Jawa Tengah,” Bioteknologi, vol. 10, no. 1, pp. 6-14, 2013, doi: 10.13057/biotek/c100102.

[4] S. Fatchurrozak, Suranto, "Pengaruh Ketinggian Tempat Terhadap Kandungan Vitamin C dan Zat Antioksidan pada Buah Carica pubescens di Dataran Tinggi Dieng," El-Vivo, vol. 1, no. 1, pp. 324, 2013.

[5] A. S. Supono, Sugiyarto, "Potensi Ekstrak Biji Karika (Carica pubescens) sebagai Larvasida Nyamuk Aedes Aegypti," El-Vivo, vol. 2, no. 1, pp. 78-89, 2014.

[6] E. B. Minarno, "Skrining Fitokimia dan Kandungan Total Flavanoid Pada Buah Carica pubescens Lenne \& K. Koch di Kawasan Bromo, Cangar, dan Dataran Tinggi Dieng,” el-Hayah, vol. 5, no. 2, pp. 73-82, 2015, doi: 10.4269/ajtmh.1986.35.167.

[7] I. dan M. Ulfah, "Uji Aktivitas Antioksidan Ekstrak Etanol Daun Karika (Carica pubescens) dengan Metode Dpph Beserta Identifikasi Senyawa Alkaloid, Fenol, dan Flavonoid," in Peluang Herbal Sebagai Alternatif Medicine, 2015, pp. 105-111.

[8] A. Laily, AN dan Khoiri, "Identifikasi Senyawa Antidiabetes secara in Silico Pada Carica pubescens Lenne \& K. Koch," el-Hayah, vol. 5, no. 4, p. 135, 2016, doi: 10.18860/elha.v5i4.3469.

[9] N. Polunin, Pengantar Geografi Tumbuhan dan Beberapa Ilmu. Serumpun. (diterjemahkan oleh : Gembong Tjitrosoepomo). 1990.

[10] T. Budiyanti, "Mengenal Morfologi Bunga Untuk Meningkatkan Kualitas Benih Pepaya," Iptek Hortik., no. 12, pp. 70-74, 2016, [Online]. Available: http://repository.pertanian.go.id/bitstream/handle/123456789/6897/13. Tri Papaya.pdf?sequence $=1$.

[11] S. \& H. Pastor, R, Galan, "Evalution of papaya autogamy,” vol. 45, no. 4, pp. 387-91, 1990.

[12] Y. Chan, "Breeding papaya (Carica papaya L.), in Mohan Jain, S \& Priyadarshan, PM (ed.)", Breeding plantation tree crops: Tropical Specie. 2009.

[13] R. Nakasone, HY \& Paull, Tropical fruits, vol. CAB Intern. 1998. 